\title{
Hesitancy as ethics ${ }^{1}$
}

Jette Kofoed jeko@edu.au.dk

Dorthe Staunæs dost@edu.au.dk

\begin{abstract}
In this paper we suggest hesitancy as ethics as a research strategy for researchers in the midst of fieldwork. We focus on the uncomfortable, unclear and uncertain aspects of researcher subjectification in fieldwork and argue that such uncertainty promises potential when it comes to stipulating ethical requirements and strategies. The suggested strategy involves assuming uncertainty as part of the researcher's position and approach, as well as insisting that research also includes an ethical obligation to 'not be too certain'. In the paper we expand upon this by suggesting five possible components of a different kind of intervention into fieldwork in what we label high intensity zones.
\end{abstract}

Key words: Ethics, hesitancy, affective methodology, researcher subjectification, fieldwork

\section{Introduction}

In this paper, our ambition is to contribute to the use of ethical hesitancy as a strategy for researchers in the midst of fieldwork. In particular, this strategy could be utilised by researchers studying zones of high intensity. We use the term 'zones of high intensity' to describe social zones that are intensive in a variety of different ways. For example, this may refer to politicised intensity, intensity in the form of battles around normativity as well as intensity focused around a specific conflict situation.

The strategy we present in this paper should be useful for researchers in the field when they are faced with affectively distressed, concerned, upset, action-oriented participants, managers, politicians, family members or others who think that 'something should be done', so that this or that 'problem can be resolved'. Thus, it is a strategy that is aimed at the researcher's participation in a specific part of the research process; namely, fieldwork.

The development of the concept of ethical hesitancy is based on research into processes of extreme exclusion among children and cyberbullying (i.e., bullying where digital media, such as mobile telephones and social media, are involved). In this type of research, appeals are often made to 'help the little ones', 'punish the wrongdoers' and to establish new rules, policies, governance and management of social relations (Kofoed, 2013a). Similarly, there is an unmistakable expectation that a committed researcher is obliged to and invested in developing interventions. The researcher quite literally becomes a powerful figure who can be invested in ongoing politics and more or less dubious agendas. This also entails that the researcher can be invited in as a figurehead for many different individuals or groups who are interested in being associated with the researcher (Staunæs \& Bramming, 2011). A particular feature of this type of fieldwork in high intensity zones is that the

\footnotetext{
${ }^{1}$ This paper has been reworked for an international audience, from Kofoed, J. \& D. Staunæs (2013). En etisk forsvarlig tøven. I: Konflikt i kvalitative studier [Conflicts in qualitative studies], Tanggaard, L., F. Thuesen \& K. Vitus (eds)., Copenhagen, Hans Reitzels Forlag.
} 
researcher enters into an articulated and explicit conflict ${ }^{2}$. This sets the scene in a different way in comparison to fieldwork in which the researcher studies everyday life in some context or another, which does not necessarily and fundamentally imply that conflict is involved. Thus, in this paper, we allow the analysis to take shape through conflicts that are articulated or that have erupted. Our analytical focus is on the necessity of an ethical strategy whose formulation is based on experiences with the momentum of articulated conflicts. In such situations, some individuals or groups are in conflict with each other, and some of them experience serious negative effects from the situation and suffer as a result. Obvious suffering accentuates appeals "to do something", preferably an intervention of some kind, which seems to strike a chord with central actors in the field who unanimously want 'what is good'. We are aware that our claim of a 'unanimous consensus' may seem like an oversimplification; indeed, it is. However, it also applies to key features of this zone of high intensity. That is, our claim is that the field of cyberbullying is characterised by widespread agreement that the adult professionals should want 'what is good' (and that we already know what is 'good') for the children who are involved in processes of extreme exclusion. It seems obvious that extreme exclusion is wrong and that the response should therefore be something better. The 'better' that the unanimous consensus is established around is often based on inclusion and wellbeing initiatives. The unanimous consensus serves as a willing narrative that overlooks the complexity and affective charge of high intensity zones. The consensus about what seems to be 'right' and 'responsible' makes it difficult to diverge from the path of the 'will to include' (Kristensen, 2012). Alongside Clare Hemmings, we emphasise the importance of challenging the well-established consensus of 'goodness', and of elucidating what she calls "the political grammar of our ways of telling stories" (Hemmings, 2011, p. 2). Furthermore, we claim that the consensus and disagreements of the research field co-constitute the potential movements of the children involved, and set the premise for how research takes shape.

Thus, the unanimous consensus ends up emotionally affecting the researcher who aims to investigate it, and takes the form of an urge to act within the very specific pathways that are presented as being relevant. It is in this way that the unanimous consensus plays a central role. As a response, we argue that ethical hesitancy may be a more useful strategy than rapid action ${ }^{3}$. Hestiancy thus means a momentary suspension of action due to an embodied sense of thoughtfulness and engaged capability of interrupting ones own immediate incentives to response and enact embedded normativities and judgements.

The first part of this paper lays out the background for interventional hesitancy and subsequently introduces the paper's theoretical resources. Later, we outline a selected case study, which allows us to address the subject of ethics as a very concrete matter in fieldwork. This case study provides the basis for an ethically focused investigation of what may constitute ethical hesitancy.

\section{The willingness of the consensus and communities of goodness}

The pressure of an 'urge to take action' in a field where actors are suffering is not an experience unique to researchers studying bullying. Indeed, ethical dilemmas and concerns come in all shapes and forms when doing research and has been widely debated (Guillemin \& Gillam, 2004). Such experience is likely to be shared by any researcher who enters politicised situations and zones of high intensity. Guillemin and Gillam outline two dimensions of ethics. Procedural ethics refer to adequately

\footnotetext{
${ }^{2}$ We would usually be interested in how conflict and bullying are two distinct phenomena, and argue that it is more purposeful to separate them than it is to compare them (Hansen, 2011; Kofoed, 2013b). However, in this paper, our focus is on the methodological and ethical implications related to fieldwork, and therefore we consider both conflict and bullying to be zones of high intensity.

${ }^{3}$ We thank Ida Hammen, Wendy Hollway, and Stine Kaplan Jørgensen, for detailed readings and pointers regarding important details in the complicated net of affectivity in fieldwork. This paper has benefited from their experiences with complicated fieldwork.
} 
dealing with informed consent, privacy, confidentiality, protection and the mantra of 'doing no harm'. The second dimension, ethics in practice deals with the grey zones, the unpredictable and yet utterly important moments and issues of ethics arising when in the field (Guillemin \& Gillam, 2004). To this Ellis (2007) adds a third dimension, relational ethics. She argues that "Relational ethics recognizes and values mutual respect, dignity, and connectedness between researcher and researched, and between researchers and the communities in which they live and work" (Ellis, 2007, p. 4). She shows how procedural ethics differs from relational ethics in pointing out how "relational ethics is the question 'What should I do now?' rather than the statement 'This is what you should do now'" (Ellis, 2007, p. 4). This question directs our query into hesitancy as well, and adds - not a fourth dimension - but rather new unfoldings of the intersection between 'ethics in practice' and 'relational ethics'. We argue for ethical hesitancy as a relevant research strategy in research involving particularly high intensity zones - for example, refugee studies, racial and ethnic studies, social psychiatry, public health, inclusion and diversity, school management in a globalised world; just to mention a few.

One might well ask why it is important to apply a strategy of hesitancy. Would it not be better to solve the problems, sort out or fix the 'unbearable lives' (Butler, 2009)? Should the researcher not just quickly contribute to the resolution of the problems that characterise their field?

Our response to both of these questions is 'yes' and 'no'. Of course, it is often appropriate to take action against suffering; indeed, this is often a necessity. Here, we argue that another type of necessity is in play; i.e., the importance of contributing to a different kind of knowledge that challenges truisms. Such dilemmas are exactly what Guillemin and Gillam addresses and what Ellis further unfolds. We add to this ongoing query of ethics by suggesting that we not only behave ethically in the situation in question during fieldwork, but also take stock of the question 'what should I do now?' beyond the current fieldwork situation we will find ourselves in. First and foremost, we maintain that the kind of research we are interested in can, in the long-term, contribute insights into complicated issues rather than providing quick solutions. We need to disrupt the urge to intervene.

We argue that researchers should allow their research to be guided by a different compass than unproblematised intervention; namely, by orientating themselves towards the research contribution itself instead of intervention development. This argument finds its basis in recognition of the sometimes almost absurd contradiction between 'long-term contributions' and 'doing good in the here of now'. Here, the contribution offers different ways of thinking and new terminologies. Allowing one's research to be guided by such a compass involves declining certain forceful and insistent invitations. It may mean that researchers will have to avoid swift catch-all solutions and refuse to participate in immediate 'communities of goodness'. Rapid action in the form of dealing with a specific conflict, such as what is described in the next part of this paper, may well ensure the researcher a comfortable position within the more established communities of goodness. If, however, the affective atmosphere in the field seems to demand action, this urge must be kept in check. If not, the result may be further suffering. For example, quick actions may intensify existing conflicts or give rise to new processes of exclusion.

In the following pages, we present the building blocks of a strategy that we consider to be an appropriate response to a slightly caricatured conflict that is seldom a case of 'either/or'; this type of oversimplification will always come up short. Nonetheless, it serves to depict a field and a topic. The field is often more complicated than it appears at first sight, and research and its normativities indeed has effects on the field that is being studied (Sedgwick, 2003, p. 124). However, the researcher in the field also acts during fieldwork and can, in these situations, be used to mobilise certain agendas and legitimise certain initiatives and opinions (Staunæs \& Søndergaard, 2008). For this reason, we need also to consider how best to navigate the potential effects of our own research behaviour (ibid.) without making the mistake of believing that we can control how the knowledge we impart will be used. 
In what follows we couple the conceptualisation of 'hesitancy as ethics' with: 1) a consideration of ethics as merely referring to national or international guidelines for research integrity and codes of conduct or, to use Guillemin and Gimmin's vocabulary, going beyond the dimension of procedural ethics; 2 ) a closer examination of the affective atmosphere of intervention that sometimes arises during fieldwork; and 3) a presentation of the five components of an ethical hesitancy.

\section{Hesitancy's theoretical precursors and unresolved questions}

In addition to the idea of ethical hesitancy in research work, we further develop the analytical considerations discussed by post-structuralists and feminists for a number of years. This line of thought is based on a long-standing preoccupation with the question of power, where (Kofoed \& Kousholt, 2011), ethics is considered to be an integral component in the development of theory and method (Dolphijn and Tuin 2012) because research is perceived as performative (Sedgwick 2003). This entails that research results do not simply reflect the world; rather research make the world accessible in specific ways and have 'real effects' on that which is being studied (Juelskjær and Schwennesen 2012). For this reason, ethics is part and parcel of research approaches, and not merely attached to research process as an afterthought. Karen Barad argues that ethics is woven into every aspect of the research process. As such, ethics is also a matter of taking responsibilty for interpersonal relationships, and of "taking into consideration the interwoven materialisations of which we are a part" (Dolphijn \& Tuin, 2012, p. 69). In alignment with Barad's focus on ethics as responsibility, we are concerned with the affective aspects of the interwoven materialisations of which we are a part. This involves that ethics must not be mistaken for moral imperatives or unambiguous guidelines on how to act: ethics itself does not dictate any direction in particular (Deleuze, 1980). It involves navigating grey zones (Hoeyer, Dahlager \& Lynöe, 2005; Markham \& Buchanan, 2012).

Informed by the above considerations, we have previously formulated analytical strategies, such as 'oscillating between critically suspicious and vitalistic, hopeful readings' (Sedgwick, 2003; Staunæs, 2007); 'creating multiple readings with the aim of disrupting claims of unambiguity'(Kofoed, 2004); 'creating temporary comparisons to displace established taken for grantedness and otherness' (Kofoed, 2007) 'a principle of interrupting the taken for grantedness by investigating its constitution and by looking at shifting minorities' (Staunæs, 2003, 2005); 'a principle of allowing more parties to appear justified'; and 'investigating both minoritisation and majorisation processes'(Kofoed, 2004, 2007). We have also pinpointed ethical requirements, such as 'avoiding adding to further exclusion' (Kofoed, 2005). These strategies and requirements are also relevant during the fieldwork and interview process. However, they are most often considered and applied in the somewhat distant location where the researcher sits and writes her analyses after she has left the field. In this phase of the research process, the researcher is seldom embedded in the many intensities of the field to the same degree; thus, she no longer experiences the intensity of its conflicts at a personal level and with her own senses. Furthermore, the researcher is no longer assailed by the urge to take action in the same intense manner.

What then are the issues that remain unresolved and require further exploration? We address the issue of the extent to which it is possible to hesitate and challenge the unanimous consensus that places demands on the researcher. We do not deny that the researcher's presence may itself be a kind of intervention. However, we pose the question: Do we know what the correct and appropriate intervention is? Do we already know in advance who is capable of deciding and initiating intervention efforts? Or might it depend on the eye that sees and the body that senses, and on how that eye or that body has been formed by its own specific academic and theoretical baggage? And, not least, might this also depend on the affective mobilisations that arise due to participation in the field? There is no doubt that professionalism, theory and an ambition to gain knowledge are aspects of the urge to take action, nor is there any doubt that professional disciplines like psychology or education (our fields) are practice-oriented in their own ways and thus presuppose particular types of action. Indeed, 
practitioners of these disciplines are expected to act. Similarly, action research and practice research all have their own requirements for intervention. But should we hesitate when faced with invitations to act regardless? And could and should we curb our urge to take action?

Is it possible to expand upon the answers that we and others have previously given, wherein we argue that a possible methodology could be comprised of proximity in the field and distance during parts of the analytical process? Might it even be possible to pinpoint which qualities are present in the way researchers are affected and affect the field (Kofoed, 2004; Thomson, Moe, Thorne \& Nielsen, 2012; Urwin, Hauge, Hollway \& Haavind, 2013)? For example, what role is played by feelings like the heroic urge to act, by fear, sympathy, or vanity? Would it be permissible to hesitate, to put the field into slow-motion and experience uncertainty?

Let us attempt to glean answers to some of these questions by exploring a specific case in which a researcher was moved by an articulated and exacerbated conflict within the field, put to the test and encouraged to engage in intervention behaviour. But in order to effectively present this analysis, we must first introduce some key concepts.

\section{Key concepts}

One key concept is what we call a majority-inclusive perspective (Staunæs, 2003). This means that it is not only those who are identified in the field as the minority (i.e., those who are inferior in terms of power) who are the object of the investigation; those who are considered to be the majority are also included as focus in the analysis. Minority/majority relations should not be understood as a matter of numbers. Rather, power relations determine who becomes the minority and who becomes the majority (Hvenegård-Lassen, 2002; Kofoed, 2004). The question of who is the minority and who is the majority is not settled from the outset; additionally, we are interested in analysing the processes through which particular individuals, experiences and groups emerge as either the minority or the majority. This also entails that we study transient minorities, which means abandoning solidarity with and concern for specific, pre-identified groups of people, and instead showing solidarity with locally emergent and transient others (Staunæs, 2004b). In a specific school context, these others could be the tough kids, the angry kids, the girls, the Grade 9 students, or the Grade 6 students. By employing a majority-inclusive perspective, the investigative lens is thus focused on fluctuations and shifts in power relations. This means that we as researchers continually seek to understand how different sides can appear justified, as also argued by Haavind et al (Haavind, Thorne, Hollway \& Magnusson, 2015). This approach allows the researcher to look at whose suffering is easy to research and write about, and whose suffering is concealed. Such a majority-inclusive perspective implies that the researcher does not, in a given (conflict-related) context, unthinkingly allow power to be exercised in the rigid forms in which it is frozen. Rather she seeks out shifting positions and changing minoritisations (Kofoed, 2013b; Staunæs, 2004a) and is willing to avoid demonstrating solidarity with a pre-given majority or minority (Staunæs, 2003, 2005).

For decades reflexivity in qualitative methods has been considered to be a productive resource in the production and understanding of empirical material. In particular, there has been discussion about the extent to which the researcher is a participant and a co-creator of the research situation itself.

Recently, reflexivity has been critizied for being too narrow a metaphor for ethnographic fieldwork because it relies on the $1 /$ eye and pushes us into metaphors of privileged views and representational ethnographies (Lynch, 2000; Schneider, 2002). However, our point is that research reflexivity, or embodied thougthfulness, as we prefer to call it, is not only a matter of the gaze or cognition but also of affectivity; i.e., the intensity and weight of the atmosphere, the moods, feelings, senses and intuitions through which the researcher experiences and interacts/intra-acts with the object of study. In recent years, there has been a particular focus on how researchers can prepare themselves to listen and participate in a sensitive manner (Back, 2007; Elliott, Ryan \& Hollway, 2012) by prioritising what Les Back calls "the art of listening" (Back, 2007). Like Julian Henriques, Back argues that it is necessary 
for researchers to hone their research senses of listening and "thinking through sound" (Back, 2007; Henriques, 2011); he thereby reminds us that the researcher him/herself is the primary investigative tool in ethnographic work. We are used to the idea of honing the researcher's senses because the researcher is the instrument that produces good empirical material. This type of saturated data is created by using a precisely calibrated instrument and, in fieldwork situations, that instrument is the researcher herself. This also means that the researcher's senses must be adjusted to create a particular type of empirical material. Lisa Blackman and Couze Venn point out how a research interest in feelings and vibrations (as in for instance cyberbullying) focuses attention on "the excess of the speakers" practices (Blackman \& Venn, 2010: 15); i.e., what extends beyond the spoken word in a fieldwork situation.

\section{An extremely unpleasant real-life conflict}

As part of a larger fieldwork project about cyberbullying, a researcher met three 13-year-old girls who were in conflict with each other. After a week of fieldwork - during which the head of the school, teachers, and students had all been made aware that the researcher was focusing on cyberbullying one teacher told the researcher that there was an ongoing issue involving social media, mobile phones, a Grade 8 class and several students from Grade 7. The atmosphere in Grade 7 was intense, and the school's corridors were buzzing with agitated voices comparing stories, seeking new information about the development of the conflict and the involvement of the various parties. Both subdued and loud inquiries about who was currently happy, excited, unhappy or worried could be heard in the corridors. The conflict was clearly articulated, and the atmosphere was tense. This led the researcher to focus on the ongoing issue, and she interviewed a number of students from the Grade 7 classes.

The unpleasant conflict is briefly described here, with the sole intention of outlining the context for the ethical points that are made in this paper. This specific conflict stirred up a range of past clashes, which meant that individual and group agitations were readily fuelled by earlier confrontations. Therefore, there were not only tensions between the students who were directly involved but also among a larger group who were rapidly drawn into the conflict. The conflict did not remain confined to the students in a single class; it extended to students from several other classes as well as a number of teachers. When a message posted on a social networking site escalated the conflict, the nonsimultaneity in emotional intensity among the parties was increased, and an unknown number of people became familiar with the feelings and outbursts of the individuals who were directly involved ${ }^{4}$.

After being interviewed by the researcher, two of the girls who were involved in the conflict approached her again and asked her to "talk with them". The invitation was an expression of the girls' desire for assistance in solving the challenges they were facing, as well as an intrusive discomfort at continuously being part of a conflict that appeared to be unresolvable to them. One of the girls, Simone, explained why she felt it was necessary to invite the researcher to help:

I feel like the adults just say, "You should become friends, and that's that." [...] Don't take it personally, but I would prefer to talk to you because you listen more than the other adults. If it were Søren, he'd just say something like, "Well, we don't have time for that. Just make up."

At first, Simone explained her desire to involve the researcher by referring to the severity of the conflict and the discomfort that was associated with it. Aisha, who was involved in the same conflict, explained why they wanted to talk to an adult other than their teacher:

They don't understand. They think it's just [young] people arguing [...] because Amalie, she gets really upset by some things. She feels like she's being bullied, and they don't understand that.

\footnotetext{
${ }^{4}$ More detailed analyses of similar cases can be found in Kofoed \& Ringrose 2012; Kofoed 2013b.
} 
They just think, "Yeah, yeah, she can handle it." [In their view,] it's just a little argument, but I think it's getting really serious.

According to Aisha, the situation had deteriorated after the issue was taken up in the head manager's office.

Allow us to put this narrative into slow motion for a moment, in order to point out that these students' statements are not presented here to celebrate the researcher as a better conversational partner than the girls' teachers or the head manager. Nor are they presented to show that the teachers had failed to take responsibility for addressing social relations at the school. The students who are quoted here were not identifying their teachers as 'wrong' in some way; rather, they were attempting to include the researcher in a specific conflict situation. From Aisha's point of view, the head manager had not been able to "do anything". Nonetheless, the girls felt that they had to talk to each other because "even though I'm really angry at [Selma], I just want to get it out, to talk to her about it".

Thus, Aisha and Simone wanted assistance in handling the conflict that was preventing them from progressing unhindered through their school lives, and which weighed upon them during this period, creating unpleasant intensity and uncertainty. Parenthetically, it is worth noting that their belief that they needed conversational help to resolve the conflict is based on an idea of the Freudian 'talking cure'. Simone also said:

I'd like to be in a situation where I could just say, "Simone and Selma, can we just talk to each other?" - where no adult would be involved, and where we could just try to figure it out ourselves. And if that didn't help, then an adult could intervene.

It is also worth noting that the optimism Simone expresses here is linked to her hope that an adult's intervention would be effective and, in this case, "bring an end to the conflict" or "resolve it".

These are strategies that are widely employed at the schools with which we have had contact. A belief in the benefits of talking together and in the 'talking cure' also exists at these schools ${ }^{5}$, and the girls who invited the researcher to help were re-enacting something they had probably seen many times before. They wanted to talk about the issue, and they wanted adult assistance in doing so.

The conflict between the girls was clearly articulated: the girls and their peers were talking about it, the teachers were talking about it, and the head manager was talking about it. When these narratives were later unravelled, it turned out that far more than just one story and far more than one point of conflict were at stake. Rather, there was a network of conflict relations with no single shared focus. It was a matter of a patchwork of conflicts with widespread affective investments, and with emotional turmoil and an atmosphere of agitation that involved many different parties.

In the following section of this paper, we attempt to bring the reader closer to the turmoil in order to show the force with which the researcher was affected and invited to intervene.

\footnotetext{
${ }^{5}$ In a survey on bullying among children at the school, the research project eXBus (Exploring Bullying in Schools) also found that, when students were asked what they would do if they experienced bullying within their class, the overwhelming majority of students stated that they would "talk about it".
} 


\section{A typical invitation to intervene}

We could call the moment the girls ask the researcher to intervene a 'moment of opportunity'. It is characterised by a possibility of change and a possible moment of value. The 'change' that the girls are longing for is an alleviation of the unpleasant intensity they are experiencing. They are hoping that relations between them can be improved. Both Aisha and the situation itself call for action. But the question is: what are the researcher's ethical obligations here? Shall the researcher interfere in the ways that Simone and Aisha invite? Can the researcher allow herself to refuse?

The conflict in which the two girls are entangled is affectively charged. They are upset; envy and fear of not being part of the group are also involved. However, the affective load is not limited to the girls involved, but is also circulates and affects the researcher. This is not necessarily a matter of being envious or of wanting to be part of the popular group of girls, nor is it a matter of feeling like the girls. Rather, the intensity that is experienced in this conflict is not contained; it so to speak overspills to the researcher, and is sensed here. In addition, the researcher is also attuned by the situation; affectively speaking, she is not simply a blank slate. The invitation to intervene thus increases the intensity in a number of different ways. In brackets, we may suggest that the researcher is already affecting the situation by entering the school and definitely, when she begins interviewing the children involved in the conflict.

The researcher's affect is heightened when her own affective investment attune the encounter with the invitation. The pleasure that she experiences at being suggested as a competent observer is one aspect of the reception repertoire that is set in motion by the invitation. The desire to contribute by breaking the vicious circle is another aspect, as is the relief the researcher felt when she is recognised as someone who could make a difference. Furthermore, the fear of not being able to complete the task may have also arisen, as well as concern that the professional in the organisation might reject this type of intervention by the researcher (i.e., advising the students about specific solutions to their problem). The researcher may also experience an unwillingness to become involved in this type of conflict, as well as an unwillingness to be recruited as the author of a story that she has no desire to tell. The researcher may also have been struck by the reprehensible thought that if she does not intervene, then it might be possible to gain incredibly interesting empirical material about an intensifying conflict (which was her initial research interest, after all). And the researcher may also experience annoyance about the fact that she is being forced to confront the ethical dilemma that the little request "Would you talk with us?" places her in.

In this particular case, the researcher was affected by the invitation and was left with increased intensity in a dilemma that was actualised by the conflict between the 13-year-old students, but which also touched upon the researcher's own embodied sense of being and self-perception. The researcher entered into the field with a specific ambition to gain knowledge, and the invitation to intervene presented a challenge to this ambition - but also an opportunity to significantly increase her own 'capital of goodness' if she could contribute with a successful intervention; that is, if the conflict could be toned down or eliminated entirely. The increase in intensity occured in the meeting between the intense affectivity in the field, the researcher's own investment, the researcher's temporary loss of her own overview, and the circulation and transformations of the involved girls' affects as well as the re-evaluation of the researcher's own choices and boundaries, which was necessitated by the girls' invitation to talk.

It is no simple task to determine how the researcher should react to such an invitation, nor is it easy to deal with the type of increase in intensity that the researcher experiences in this situation. What should guide how the researcher handles being 'affectively contaminated'? The researcher had an ambition not to allow herself to be put into any one specific position or to take any particular side in the conflict. Rather, she set out to investigate a large number of (internally conflicting) justifications in an articulated conflict. She is nevertheless affected by the situation. And in spite of the researcher's ambitious and noble promises to herself to resist picking up an 'indignant pen', adding to narratives 
about goodness or identifying villains, she is affected by the many affects that assail her from the different sides of the conflict. These affects are exacerbated by her loss of footing in the situation. The researcher is moved by the oppositional mood between the girls as well as the conflicting affects within herself. Conflicts are alive and cannot be put on hold simply because a researcher is present.

As a visiting researcher, one's involvement has a certain kind of significance. The researcher is an adult - and an important one at that. At schools and among children and parents, there is an unspoken expectation that the intervention of an adult is necessary, and that this will relieve conflicts and suffering, as was apparent in the example of Aisha and Simone described above. There is an expectation that the actors in the field will share a common interest in developing interventions that can reduce bullying and ensure the well-being of students. There are obvious, intense and almost unresolvable conflicts while there is also a widespread and similarly intense desire to prevent and settle such conflicts. The fundamental idea that conflicts should be resolved is seldom questioned.

The case involving Simone and Aisha is not only special because the conflict is explicit; it is also special because it involves youth. In research into children and youth, there is a consensus - with reference to the Convention of the Rights of the Child - that children should be protected. This is difficult to debate or challenge, and indeed we do not attempt to challenge whether children have the right to be cared for and protected. Rather, we want to question, in a qualified manner, how research contributes to this and thereby encourage researchers to hesitate when they are inundated with invitations to act.

When the field involves an entanglement between suffering, the urge to intervene and imperatives of goodness, then the researcher may be subjectified in particular ways. The researcher can opt out, pass the invitation or explain that there may be other sides to the story. For some actors in the field, this may seem unethical - perhaps even offensive. Rather, the dominant athmosphere is sustained by an expectation of co-authorship of the stories that are already being told about wanting 'what is good', about preventing suffering and about contributing via an intervention. This line of argumentation and association is strong and exerts a great deal of pressure on the researcher. We suggest that one way to proceed in such situations could be to intervene in the demand for intervention in order to bring about a destabilisation of the scripts that are embedded within it. In the next section of this paper, we expand upon what we mean by 'intervening in the demand for intervention' by suggesting five possible components of a different kind of intervention.

\section{Intervening in the demand for intervention, and the components of a different kind of intervention}

The following five components make up the ethical hesitancy that we are proposing as a relevant strategy for handling the researcher's ethical challenges in highly intense research zones. Hesitancy is an attempt to deal proactively with research practices and their ethical implications. Therefore, the points presented below are components of an ethical navigation skill, and should not be understood as moral imperatives for fieldwork and they do not include catch-all solutions that can be used in all fieldwork situations. These components were developed during an in-depth investigation of the case being discussed here, along with other experiences from different fieldwork situations. In this investigation, we do not claim that there were no other possible courses of action. Nor do we claim that one cannot question the researcher's movements in the field. In such grey zones of ethics, however, there is a need for a language to enable us to talk about how to handle ethical challenges. We use the case presented here as a tool to explore the potential of an ethical hesitancy.

\section{Loosening the ties between the 'goodness scripts', interventions and research}

The field of practice in which this case took place is, as we have already mentioned, characterised by articulated conflicts as well as a strong normative embeddedness in generalised and specific desires to 
'want what is good'. This is interwoven with what we call 'goodness scripts'. To a great extent, they draw upon "a political and educational truism of inclusion" (Langager, Schmidt \& Øster, 2012). In the field of bullying (both in schools and within the research communities), this goodness script often takes the form of an expectation to reduce bullying and promote wellbeing. This expectation can be felt as a goodness script that is difficult to object to. Nevertheless, we want to point out that this very script also inhibits and 'tames' the researcher, due to its expectation that goodness shall be exercised via the desire to translate research results into concrete interventions. Within the fieldwork situation itself, there is also pressure on the researcher to apply knowledge rapidly, preferably in the form of good advice about how this or that case can and should be handled. Based on our experiences with these types of ties between goodness scripts, intervention and research, we suggest that some research contributions can more readily come into their own and make a difference, if the close ties between goodness scripts, intervention and research are loosened. Such a loosening of ties would require both the involvement and distancing of the researcher, as it opens up the possibility to reject forced co-authorship of the field's implicit narrative. Hence, it becomes a matter of opening up the dominant narrative forms in order to tell a different story.

In the case at hand, this loosening - within the fieldwork situation - is a matter of refraining from accepting the invitation to join a formalised conversation with the girls who asked the researcher for help in resolving their conflict. The researcher withdrew from an immediate incitement to act by offering the explanation that her competences do not include intervention and conflict resolution (even though what needed to be done in the situation may have been obvious). The researcher also justified her refusal of the invitation to intervene with her concern about whether an unqualified researcher's intervention would add to the suffering and thereby increase the conflict as well as the number of parties involved; i.e., a hesitancy based on whether or not the researcher actually has what it takes to perform the task of conflict resolution in a sufficiently qualified manner to avoid worsening the situation. The researcher's refusal was also based on her doubts about whether she could commit herself to the extent that would be required. The decision to withdraw was made with reference to the 'long-term' contributions of the research that we mentioned earlier. This decision was made possible by the loosening of ties between the goodness script, intervention and research. However, the decision was only possible in combination with some of the components we describe below.

\section{Obtaining a refractive space and involving colleagues}

The researcher seeks a refractive space in order to allow alternative strategies to the one that seemed self-evident in the field (i.e., talking to the girls immediately) can emerge. Refract means to bend (light, sound and heat e.g.). Studying the way in which the waves are refracted, the way they continue and change as they pass on, provides insight into the characteristics of and relationship between the media and loci that the various kinds of waves traverse, whether they are light waves, electromagnetic waves or sound waves (Haraway, 1992). Using the word refractive here is an attempt to put forward how interactions, talks, sharing of moments e.g. with others may help to bend and differentiate ways of thinking-feeling. A refractive space is not reflective in the sense of mirroring or throwing the thoughts and feelings back in the same direction or the opposite, but to open up spaces of other possible indexes and to facilitate readings of differences and of a different kind (see also (Juelskjær \& Staunæs, 2016, in press; Lafton, 2015).

The researcher seeks assistance from outside the field as well as from outside her immediate professional environment in order to understand the specific situation and to challenge her own understandings and reactions. Forming such refractive spaces and the involvement of colleagues when deciding how to act becomes one concrete way to build hesitancy into fieldwork. In this case, the formal supervision and more informal refractive space contribute to an exploration of the researcher's own research position and her own affective investment in the research field and the concrete situation. This also contributes to the shaping of new research insights; e.g., types of analysis that are (partially) liberated from the goodness scripts of the field. Elliott et al. use a similar argument 
when they point out how containment and the shaping of such spaces among colleageues represent a particular space in which researcher subjectificationn can become the object of investigation (Elliott et al., 2012). Such a formalisation of containment would clearly be able to provide a space in which to explore researcher subjectification, which is often subject to stringent demands in the field where the researcher is the seismograph that must be 'fine-tuned' and practice 'the art of listening'.

Furthermore, refractive spaces make it possible to talk about the field without breaching agreements about confidentiality and anonymity. This kind of formalisation of sharing embodied thoughtfulness could contribute to the creation of an ethical practice in the creation of new knowledge. Thus, the opportunity to receive supervision or more informal shared thoughtfulness is not only significant for the wellbeing of the researcher and her process of self-reflection - it is also important in the processes of data production and interpretation (Elliott et al., 2012). In this context, a shared refractive space has the potential to ensure that the researcher does not get off track in her fieldwork. It also gives her the opportunity to consider intensity, embodiment and complexity in fieldwork. In our case, the researcher's participation in the field is interrupted due to having to determine how to respond to the girls' invitation to intervene. For the researcher, such a refractive space and having discussions with colleagues provide a space in which to de-personalise her observations and possible actions - to widen herself, so to speak, by including the perspectives of her colleagues. It also provides an expanded space for reflection and, in this way, it allows the researcher to find a way to exercise ethical hesitancy. In this case, it was a matter of declining the girls' invitation. In some cases, however, it may be necessary for the researcher to report occurrences or situations that have been revealed during their fieldwork, either by contacting teachers, heads of school or school psychologists. They may involve abuse or violence, which extend beyond the bounds of the goodness scripts and require action of some kind in accordance with clear ethical guidelines (e.g., the ethical codes produced by associations of sociologists, anthropologists, psychologists or the international scientific ethical guidelines that go beyond disciplines); such cases are different from the one described here.

\section{Adjusting the pliability of the stories}

The invitation to intervene is embedded in a number of stories about the field - about the self-evident nature of inclusion and about the necessity of goodness. There is a certain resonance between these stories. This resonance also creates strong affective ties that the researcher must take into consideration. However, in the case at hand, the invitation was also embedded in other stories within the field. The invitation to intervene and the hope that 'talking would cure' also contain concrete yet partial stories about one side of the conflict; in these, the other party appear to be incomprehensible. Such stories are strongly stated with an element of unambiguity that leaves little space for alternative understandings. Stories readily change according to the requirements of the field. Thus, the selfevident nature of inclusion and the necessity of goodness are not absolutes. Rather, they are mutable and amenable in relation to the requirements of the field. It is in and through their amenability that such stories maintain their strength.

Thus, the third component in an intervention is to adjust the amenability of the stories in and about the field (Hemmings, 2011). We argue that the majority-inclusive perspective that is drawn from minority research - and which we described earlier in this paper - is particularly suitable when it comes to challenging the normative and politicised narratives into which research becomes entangled. Adjusting the amenability of the stories involves identifying what is taken for granted in the specific context, and then asking to what extent the overarching narratives about the self-evident nature of inclusion and the necessity of goodness actually meet the concrete requirements of the given context.

In the case described here, this means further examining the girls' invitation and talking to other parties who were not immediately considered to be involved in the conflict (e.g., the boys who are not directly involved, but who are in the vicinity), modifying the certainty that the other party was incomprehensible and the understanding that the situation called for adult conversational assistance. 
Similarly, Butler (2005) argues that an ethical position involves the awareness that every account is partial, preliminary and open to interpretation (Butler, 2005). She reminds the reader that ethics are not only a matter of refraining from violence against the other, but are also a matter of being nonviolent towards oneself. If we take into consideration Butler's point about partial accounts, together with Hemmings' point about how strong narratives survive due to their own amenability, then we are already a step closer to being able to shift what might otherwise appear to be firmly established stories of unambiguity. Indeed, there may well be cracks in these stories that the researcher could be invited to fix. Furthermore, Butler's point about the open-endedness of stories serves as a reminder that, while researchers have the opportunity to disrupt, they also have an obligation not to close off their own stories too quickly (Elliott et al., 2012). Thus, adjusting the amenability of stories is not about telling new (corrective) stories. Rather, it is a pointer towards the potential of experimenting with alternative ways of telling stories about the field and about the positioning of the researcher. In this way, it is an attempt to experiment with embodied hesitancy.

\section{Circumventing the prevailing political grammar}

The researcher is positioned as an active and acting subject with a particular agency - often as a potential saviour when the invitation to intervene is a matter of stories about goodness and intervention imperatives. If we make use of Clare Hemmings' insights into the importance of the prevailing political grammar (Hemmings 2011, p.7), we are able to deduce how the local stories into which the researcher was invited present themselves as a relevant model with which to understand research and its dilemmas. We also become aware of how the other stories are obscured. As we have already mentioned, the model through which this particular kind of research is most readily understood is dominated by goodness scripts. What then is the researcher to do with such an invitation? What is the alternative to writing in accordance with the story that is being proposed? Both the small story 'adult intervention can help us out of the conflict' and the larger story 'we, who help children solve their conflicts, do so out of goodness' laid out the conditions for the researcher's possible actions. Correcting the widespread stories and offering more comprehensive and richer versions of the stories (Hemmings 2011, p. 12) is one way in which the researcher can tell alternative stories without concluding that they are necessarily better. However, such richer stories will not solve the dilemma by themselves. Telling alternative stories have become part of the analyses of the empirical material that is produced in this kind of fieldwork (Henningsen, Hansen \& Kofoed, 2013; Kofoed, 2013b; Kofoed \& Ringrose, 2012), however, this is far from sufficient to solve the dilemma we describe here. In this specific fieldwork, the conflict of researcher subjectification is heightened; alternative stories forme in the researcher's notebooks and mind, but does not make their way to the girls involved in the conflict in the form of new stories. Instead, in this case, one of the key components of ethical hesitancy is the investigation and circumvention of the political grammar of which the specific invitation is a part, as well as the affective grammar used in the invitation; namely, the goodness script and the participation of adults in the community who assume the task of inclusion by acting swiftly in the fieldwork situation. Observing the significance of the affective grammar became a key component of daring to hesitate.

\section{Curbing vanity}

In the specific invitation to intervene, the researcher experienced several conflicting affective reactions, ranging from satisfaction and delight at being recognised as a relevant participant and conversational partner to discomfort and unwillingness to be identified as a competent researcher with a rapid catch-all solution up her sleeve. However, the researcher's emotional reactions did not only arise when she was invited to participate in 'talking the cure'. Rather, they started earlier while the extremely unpleasant conflict was playing out. At this point, the researcher already started to sense the different parties' violent reactions and to co-live the statements 'Sandra is really too much', 'It's really vulnerable to be in Sandra's position', 'Selma should pull herself together' and 'Søren should really start getting involved a bit here'. We mention a few different names here to illustrate how different people in the school landscape may attract sympathy, correction and/or concern. 
Furthermore, we do this to show that the different reactions are most often directed at subjects, even though they are not necessarily fixed there. Our point is that the researcher was embedded in the landscape of conflict early on and was pulled in different affective directions that were not necessarily consistent or appropriate. Another point is that the way the researcher is affectively attuned and attunes the field; for example, happiness about gaining access to the field, surprise at the scope of the conflict, discomfort due to its intensity and the difficulty in gaining access to the different actors at the school. And none of this is innocuous. All in all, it is one big mess. So when the 13-year-old girls invited the researcher into the conflict, the intensity increased. However, this should not be understood in isolation but should instead be considered alongside the conflictual atmosphere that preceded it, which also affected the researcher. So, when the girls called upon the researcher, a delicate situation arose in which the researcher at first sensed the urge to help them and the pleasure of being recognised as a relevant conversational partner. In the hesitancy that was subsequently put into practice, the researcher began to curb an urge to be the hero who could save the community; i.e., the desire of being able to make a very specific type of difference. But curbing these desires does not mean they should be eradicated from the researcher's repertoire in order to make room for others, but to make room for an ethical way of dealing with the girls' invitation. Curbing her desire to accept the invitation was only the first step. If we are to make use of the researcher's embodied senses and feelings in order to talk about the art of listening as a way to achieve knowledge and insights, then access to affective reactions must not stand-alone. Affective experiences coupled with time for embodied thoughtfulness have the potential to provide substantial insights into both researcher subjectification and into different research fields. Creating structured opportunities for reflection that go beyond those that are immediate could be a productive way to build time for reflection and refraction into the research process.

\section{Stretched between certainty and uncertainty}

In this paper, we have outlined a possible ethical approach to the challenges presented by fieldwork. This outline is based on a range of tensions and conflicts experienced in our own research. This also means that what we have presented here is positioned on a tightrope between certainty and uncertainty, or what Pillow calls "a move out of reflexivity's comfort zone" (Pillow 2003) and which we initially posited as residing at the intersection between 'ethics in practice' and 'relational ethics'. This move takes us to a place where there is doubt and pain. The tension between certainty and uncertainty is not only relevant to the particularity of the fieldwork we have presented here; it is also relevant to ethical hesitancy itself. This kind of ethical hesitancy moves along the same tightrope between knowledge and non-knowledge, between certainty and uncertainty. In many respects, these tensions are preconditions for qualitative research. We argue that the tension enriches fieldwork, and that it can be handled in ways that do not lead to not knowing and uncertainty being weeded out of the fieldwork process because they are problematic to deal with and because researchers prefer more comfortable researcher subjectifications. Rather, the uncomfortable, unclear and uncertain aspects of researcher subjectification in fieldwork contain potential when it comes to stipulating ethical requirements and strategies that may make it possible to take a refined and inquisitive approach to qualitative research work. Therefore, we argue that not knowing and uncertainty are important for research processes and, in this case, they were relevant to the fieldwork phase of the research process. As Barad explains in an interview: "Ethical considerations can't take place after the facts are settled, after the research is done. This is the wrong temporality. Values and facts are cooked together as part of one brew." (Juelskjær \& Schwennesen, 2012, p.15-16). Thus, the type of ethical hesitancy we advocate here is an embodied thoughtfulness that includes discomfort and uncertainty (Pillow, 2003). This discomfort is integral in developing ethics because it is based on an explicit desire to not perpetuate strong narratives about appropriate goodness, and because it is not founded in an unhelpful opposition between 'long-term contributions' and 'doing good in the here of now'. 
However, not knowing and uncertainty are not always workable as 'permanent' elements. Of course, we must be able to arrive at some form of resolution or another, with regard to either the specific challenge being faced (in this case, the conflict and the resulting invitation to intervene) or to the state of the field and researcher involvement on a more general level. It is not possible to predict how the researcher will be drawn into the field. The ethical hesitancy in fieldwork we outline here is a strategy for keeping open the unpredictable challenges presented by concrete encounters during fieldwork. It is also a way to accept the preliminary nature of the knowledge that is created via this kind of fieldwork. Thus, hesitancy can be understood as a strategy for manoeuvring through an unavoidable part of the research process; i.e., dealing with uncertainty. This strategy involves assuming uncertainty as part of the researcher's position and approach, as well as insisting that research also includes an ethical obligation to 'not be too certain'. This allows the analyses to emerge from uncertainty rather than from previously established certainty about the requirements of a given field. Hesitancy also implies a promise that 'something next' will follow from this hesitancy. Hesitancy is, by definition, not permanent, and does not imply that we reject knowing on a permanent basis. Rather, hesitancy brings about a pause during which the pace is reduced. Or we might say that the researcher temporarily brackets off a particular event or challenge. The assumption is that this pause allows the researcher to struggle with and perhaps go beyond initial impulse and incentives. If strategies and guidelines are established with regard to this process, it might also be possible for the researcher to consider aspects of the immediate situation that are more difficult, more complicated or less simple to resolve and respond to.

Therefore, temporality plays a key part in hesitancy as a responsible ethical strategy. Hesitancy requires time, the opportunity to postpone action and a chance to 'put the situation on hold'. We argue that the pace with which we can create new knowledge and new insights is qualified by such pauses. Therefore, the paper can be summarised as follows: When one is pushed outside of one's comfort zone, temporality, qualified thinking and feeling and hesitant ethics can guide researchers through their fieldwork and ensure that the knowledge they create is not detached but is ethical. Hesitancy as an ethical act within these tensions is a strategy for intervening in the urge to intervene.

\section{Literature}

Back, L. (2007). The Art of Listening. London: Berg.

Blackman, L. \& Venn, C. (2010). Affect. Body \& Society, 16(7), 7-28. http://dx.doi.org/10.1177/1357034X09354769

Butler, J. (2005). Giving an account of oneself. New York, NY: Fordham University Press. http://dx.doi.org/10.5422/fso/9780823225033.001.0001

Butler, J. (2009). Frames of War. When Is Life Grievable? London, New York: Verso.

Deleuze, G. (1980). Spinoza. Ontology - ethics. Les cours de Gilles Deleuze.

Dolphijn, R. \& Tuin, I. v. d. (2012). New Materialism: Interviews \& Cartographies: Open Humanities Press. http://dx.doi.org/10.3998/ohp.11515701.0001.001

Elliott, H., Ryan, J. \& Hollway, W. (2012). Research encounters, reflexivity and supervision. International Journal of Social Research Methodology, 15(5), 433-444. http://dx.doi.org/10.1080/13645579.2011.610157

Ellis, C. (2007). Telling Secrets, Revealing Lives: Relational Ethics in Research With Intimate Others. Qualitative Inquiry, 13(1), 3-29. http://dx.doi.org/10.1177/1077800406294947

Guillemin, M. \& Gillam, L. (2004). Ethics, Reflexivity, and "Ethically Important Moments" in Research. Qualitative Inquiry, 10(2), 261-280. http://dx.doi.org/10.1177/1077800403262360

Hansen, H. R. (2011). Lærerliv og elevmobning. [Teachers' lives and student bullying]. Ph.D.dissertation, University of Aarhus, Denmark

Haraway, D. (1992). The Promises of Monsters: A Regenerative Politics for inappropriate/d Others. In L. Grossberg, Cary Nelson, P. A. Treichler, L. Baughman, \& J. M. Wise (Eds.), Cultural Studies. New York / London: Routledge. 
Hemmings, C. (2011). Why stories matter? London: Routledge.

Henningsen, I., Hansen, H. R. \& Kofoed, J. (2013). When classroom culture tips into bullying. In R. M. Schott \& D. M. Søndergaard (Eds.), Shool Bullying: New Theories in Context. Cambridge: Cambridge University Press.

Henriques, J. (2011). Sonic Bodies. Reggae Sound Systems, Performance Techniques, and Ways of Knowing. London, NY: The Continuum International Publishing Group.

Hoeyer, K., Dahlager, L. \& Lynöe, N. (2005). Conflicting notions of research ethics. The mutually challenging traditions of social scientists and medical researchers. Social Science \& Medicine, 61, 1741-1749. http://dx.doi.org/10.1016/j.socscimed.2005.03.026

Hvenegård-Lassen, K. (2002). På lige fod. Samfundet, ligheden og folketingets debat-ter om udlændingepolitik 1973-2000. [On equal terms. Society, equality and parliaments debates on immigration 1973-2000]. (Ph.D.-dissertation), University of Copenhagen

Haavind, H., Thorne, B., Hollway, W. \& Magnusson, E. (2015). "Because nobody likes Chinese girls": Intersecting identities and emotional experiences of subordination and resistance in school life. Childhood, 22, 300-315. http://dx.doi.org/10.1177/0907568214549080

Juelskjær, M. \& Schwennesen, N. (2012). Intra-active Entanglements - An Interview with Karen Barad. Kvinder, køn og forskning, 1-2, 10-24.

Juelskjær, M. \& Staunæs, D. (2016, in press). Orchestrating intensities and rhythms. How postpsychologies are assisting new educational standards and reforming subjectivities. Theory and Psychology (special issue on standards and subjectivities).

Kofoed, J. (2004). Elevpli. Inklusion-eksklusionsprocesser blandt børn i skolen. (Ph.d.-dissertation), [Polished pupilness. Processes of inclusion and exclusion among children in school]. The Danish University of Education, Copenhagen.

Kofoed, J. (2005). Elevpli. Arbitrære punktummer i skoleliv og forskning. Nordiske Udkast. Tidsskrift for kritisk samfundsforskning, 2. [Arbitrary fullstops in schoollife and research. Nordiske Udkast. Journal of critical research].

Kofoed, J. (2007). Ansvar for egen elevhed. Suspensive komparationer på arbejde. In J. Kofoed \& D. Staunæs (Eds.), Magtballader. 14 fortællinger om magt, modstand og menneskers tilblivelse. [Responsible for your own pupilness. Suspensive comparisons at work. I: . Power troubles. 14 narratives of Power, Resistance and Human Becoming]. Copenhagen: Danish University of Education.

Kofoed, J. (2013a). Affektive rytmer. Spektakularitet og ubestemmelighed i digital mobning. In J. Kofoed \& D. M. Søndergaard (Eds.), [Affective rhythms. Blatant and subtle aspects of cyberbullying In: Rethinking Bullying] Mobning gentænkt. Copenhagen: Hans Reitzels.

Kofoed, J. (2013b). Non-simultaneity in cyberbullying. In R. M. Schott \& D. M. Søndergaard (Eds.), Shool Bullying: New Theories in Context. Cambridge: Cambridge University Press.

Kofoed, J. \& Kousholt, D. (2011). Etiske fordringer og multiple temporaliteter. [Ethical claims and multiple temporalities In Nordiske Udkast. Journal of Critical Research]. Nordiske Udkast. Tidsskrift for kritisk samfundsforskning, 1/2, 1-7.

Kofoed, J. \& Ringrose, J. (2012). Travelling and sticky affects: Exploring teens and sexualized cyberbullying through a Butlerian-Deleuzian-Guattarian lens. Discourse: Studies in the Cultural Politics of Education, 33(1), 5-20. http://dx.doi.org/10.1080/01596306.2012.632157

Kristensen, J. E. (2012). Viljen til inklusion - en samtidsdiagnostisk indkredsning. [The will to inclusion an socialdiagnostic approach In Danish Journal of Education]. Dansk Paedagogisk Tidsskrift, 4, $50-60$.

Lafton, T. (2015). Refleksjoner og handlinger i barnehagens møter med teknologi. Sosio-materielle teorier som optikk for (re)konstruksjoner av barnehagenprasksiser. Institutt for pedagogikk. (Ph.D. submitted]. Universitetet i Oslo. [Reflections and actions i meetings between kindergarden and technology. Socio-material theories as lens in (re)constructions of kindergardenprocesses]

Langager, S., Schmidt, M.-C. S. \& Øster, B. (2012). Inklusionens selvfølgelighed? [The taken for grantedness of inclusion In Danish Journal of Education]. Dansk Pædagogisk Tidsskrift, 4, 2-5. 
Lynch, M. (2000). Against Reflexivity as an Academic Virtue and Source of Privileged Knowledge. Theory, Culture \& Society, 17(3), 26-54. http://dx.doi.org/10.1177/02632760022051202

Markham, A. \& Buchanan, E. (2012). Ethical Decision-Making and Internet Research: Recommendations from the AOIR Ethics Committee. Retrieved from http://aoir.org/reports/ethics2.pdf

Pillow, W. S. (2003). Confession, catharsis, or cure? Rethinking the uses of reflexivity as methodological power in qualitative research. Qualitative Studis in Education, 16(2), 175-196. http://dx.doi.org/10.1080/0951839032000060635

Schneider, J. (2002). Reflexive/Diffractive Ethnography. Cultural Studies <-> Critical Methodologies, 2(4), 460-482. http://dx.doi.org/10.1177/153270860200200402

Sedgwick, E. (2003). Touching Feeling: Affect, Pedagogy, Performativity. Durham, N.C.: Duke University Press.

Staunæs, D. (2003). Where have all the subjects gone. Bringing together the concepts of subjectification and intersectionality. NORA, 11(2), 101-110. http://dx.doi.org/10.1080/08038740310002950

Staunæs, D. (2004a). Etnicitet, køn og skoleliv. [Ethnicity, gender and schoollife In Nordiske Udkast, Critical Journal of Research]. Nordiske Udkast, 31(2), 28-40.

Staunæs, D. (2004b). Om mangfoldighed og diskurslukninger: Takketale ved modtagelse af Krakaprisen 2004. [On diversity and closures of discourses. Acceptance speech when receiving the award of Kraka In Women, Gender and Research]. Kvinder, køn og forskning, 14(2-3).

Staunæs, D. (2005). From culturally avantgarde to sexually promiscuous - troubling subjectivities and intersections in the social transition from childhood into youth. Feminism \& Psychology, 15(2), 149-167. http://dx.doi.org/10.1177/0959353505051719

Staunæs, D. (2007). Subversive analysestrategier - eller governmentality med kjole, fjerboa og sari. In J. D. S. Kofoed (Ed.), Magtballader. 14 fortællinger om magt, modstand og menneskers tilblivelse. [Subversive analytical strategies - or governmentality with dress, boa and sari. Power troubles. 14 narratives of Power, Resistance and Human Becoming]. Copenhagen: Danish University of Education.

Staunæs, D. \& Bramming, P. (2011). Øyeblikksbilder og kyborghet: autofotografering og bildebasert forskning. In K. Fangen \& A.-M. Sellerberg (Eds.), Mange ulike metoder (pp. 97-109) [Pictures of moments and cyborgness. Autophotography and visual methods. In: Many different methods]. Oslo: Gyldendal.

Staunæs, D. \& Søndergaard, D. M. (2008). Who are ready for results? : Reflections on the Multivoicedness of Useful Research. International Journal of Qualitative Studies in Education, 21(1), 3-18. http://dx.doi.org/10.1080/09518390701768757

Thomson, R., Moe, A., Thorne, B. \& Nielsen, H. B. (2012). Situated Affect in Traveling Data: Tracing Processes of Meaning Making in Qualitative Research. Qualitative Inquiry, 18(4), 310-322. http://dx.doi.org/10.1177/1077800411434283

Urwin, C., Hauge, M.-I., Hollway, W. \& Haavind, H. (2013). Becoming a Mother Through Culture. Qualitative Inquiry, 19(6), 470-479. http://dx.doi.org/10.1177/1077800413482101 